HISTORIA: Jurnal Pendidik dan Peneliti Sejarah, 5(1), 1-8. https://doi.org/10.17509/historia.v4i2.30197

Available online at HISTORIA; Jurnal Pendidik dan Peneliti Sejarah
Journal homepage: https://ejournal.upi.edu/index.php/historia

\title{
ENRICHMENT MATERI PEMBELAJARAN SEJARAH TENTANG PERANAN PERANAKAN ARAB PADA MASA PERGERAKAN KEMERDEKAAN
}

\author{
Iing Yulianti ${ }^{1}$, Yeni Kurniawati Sumantri ${ }^{1}$, Afis Winarko ${ }^{2}$ \\ ${ }^{1}$ Prodi. Pendidikan Sejarah, Universitas Pendidikan Sejarah \\ ${ }^{2}$ SMA Labschool Universitas Pendidikan Indonesia \\ Correspondence: iingyulianti@upi.edu
}

To cite this article: Yulianti, I., Sumantri, Y. K., \& Winarko, A. (2022). Enrichment materi pembelajaran sejarah tentang peranan peranakan arab pada masa pergerakan kemerdekaan. HISTORIA: Jurnal Pendidik dan Peneliti Sejarah, 5(1), 1-8. https://doi.org/10.17509/historia.v4i2.30197.

Naskah diterima : 7 Desember 2020, Naskah direvisi : 7 Juni 2021, Naskah disetujui : 30 Desember 2021

\begin{abstract}
This paper is intended to develop the process of learning history by implementing enrichment on the role of the Arab Peranakans in Indonesia during the Indonesian independence movement. The historical research methodology used in this research is through heuristics, criticism, interpretation, and historiography stages. This paper refers to the results of previous studies that have reconstructed the role of the Arab Peranakans during the national movement until the period of the independence revolution. The historiography results will then be implemented through enrichment in history learning on the material from the period of the national movement to the independence revolution. This study is based on the importance of building a complete reconstruction of the role of all community groups in Indonesian history. This study seeks to examine and describe the role of Arab descendants in the history of Indonesia, especially during the struggle for Indonesian independence so that it can then be used as a supplement in history textbooks at the upper secondary education level. This study can build a complete reconstruction of historical events that can produce information, perceptions, and historiography of the role of all elements of Indonesian society in Indonesian history for the benefit of historical education.
\end{abstract}

Keywords: Arab breeds; Enrichment; History Learning Materials; Indonesian Independence Movement.

\begin{abstract}
Abstrak
Tulisan ini ditujukan untuk mengembangkan proses pembelajaran sejarah dengan mengimplementasikan pengayaan (enrichment) tentang peranan peranakan Arab di Indonesia pada masa pergerakan kemerdekaan Indonesia. Metodologi penelitian sejarah digunakan dalam riset ini yaitu melalui tahap heuristik, kritik, interpretasi dan historiografi. Karya tulis ini merujuk kepada hasil penelitian sebelumnya yang telah merekonstruksi peran peranakan Arab pada masa pergerakan kebangsaan sampai periode revolusi kemerdekaan. Hasil historiografi tersebut selanjutnya akan diimplementasikan melalui enrichment dalam pembelajaran sejarah pada materi periode pergerakan kebangsaan sampai revolusi kemerdekaan. Kajian ini dilandasi oleh pentingnya membangun rekonstruksi yang utuh tentang peran semua kelompok masyarakat dalam sejarah Indonesia. Kajian ini berupaya untuk mengkaji, menelaah, dan mendeskripsikan peran peranakan/keturunan Arab dalam sejarah Indonesia terutama pada masa perjuangan kemerdekaan Indonesia untuk selanjutnya dapat dijadikan suplemen dalam buku teks pelajaran sejarah pada jenjang pendidikan menengah atas/sederajat. Kajian ini dapat membangun rekonstruksi peristiwa sejarah secara utuh yang dapat menghasilkan informasi, persepsi dan historiografi peranan semua elemen masyarakat Indonesia dalam sejarah Indonesia untuk kepentingan pendidikan sejarah.
\end{abstract}

Kata Kunci: Enrichment; Materi Pembelajaran Sejarah; Peranakan Arab; Pergerakan Kemerdekaan Indonesia.

HISTORIA: Jurnal Pendidik dan Peneliti Sejarah, p-issn:2620-4789 | e-issn:2615-7993 


\section{PENDAHULUAN}

Pengkajian materi sejarah pada dunia pendidikan dapat menjadi sarana pengembangan kesadaran nasional. Diharapkan dengan adanya kajian ini dapat menumbuhkan juga menjadi langkah pelembagaan kesadaran nasional dalam bentuk loyalitas bagi bangsa dan negara. Bentuk kajian sejarah dapat memberikan 'pelajaran' pada manusia masa sekarang dan yang akan datang untuk dapat hidup lebih baik, terlepas sejarah sebagai sebuah peristiwa dan ditujukan bagi kepentingan pada masa lampau. Pelajaran di sini ialah sejarah sebagai pendidikan, sebuah sumbangan praktis bagi segi pengetahuan, kemampuan, keterampilan, juga afektif siswa (Sjamsuddin, 2005). Dengan memilih sebuah peristiwa sejarah masa revolusi kemerdekaan utamanya mengenai peranan kelompok masyarakat dapat menjadi sumbangan pengetahuan bagi siswa terhadap memori kolektif dan masa lalu bangsanya. Selanjutnya diharapkan menjadi pemantik kesadaran kehidupan bersama dalam komunitas yang lebih besar.

Terdapat banyak nilai yang dapat ditanam dalam pembelajaran sejarah semisal; nilai informatif, nilai pendidikan, nilai budaya, nilai estetika, nilai nasionalisme dan sebagainya (Kochhar, 2008). Nilai tersebut merupakan sumber pembelajaran sejarah yang dapat ditingkatkan juga dikembangkan bagi siswa berbagai jenjang pendidikan. Dalam artian lain pendidikan menjadi sarana yang tepat dan strategis dalam menanamkannya, dilain sisi sekolah menjadi sebuah tempat pengembangan nilai tersebut (Wiriaatmadja, 2002).

Sementara itu fungsi sejarah sebagai media ditujukan memberikan kesempatan yang bernilai bagi siswa untuk dapat mengenal masa lalu, juga tidak kalah penting ialah sebagai pengabdian pengalaman masyarakat masa lampau yang sekali waktu membantu pemecahan masalah (Renier, 1961). Sejarah yang berkaitan mengenai perubahan dan kesinambungan, memiliki banyak pelajaran dari setiap peristiwa, sehingga ketika paham mengenai sejarah maka kesalahan yang telah dibuat tidaklah ingin untuk kembali diulangi, sebaliknya sebuah keberhasilan patutnya menjadi contoh dan ditingkatkan kembali (Wineburg, 2006).

Berkaca dari urgensi pelajaran sejarah, maka menjadi tantangan juga bentuk tanggung jawab yang besar untuk menumbuhkan dan meningkatkan pemahaman sejarah terkhusus bagi generasi muda. Bermula dari keinginan untuk mewariskan pengalaman lampau yang berkaitan dengan kejayaan maupun kekalahan atau kehancuran dari sebuah peristiwa yang telah dialami manusia pada masa ke masa. Dikemas dalam bentuk pengetahuan yang berharga sebagai bekal menghadapi kehidupan yang berlanjut juga bentuk pengembangan potensi kognitif siswa untuk berpikir. Berkaitan dengan hal tersebut, siswa dapat mengembangkan kecintaan, kesetiaan, ataupun ketaatan pada negara dengan pengetahuan juga apresiasi dan pemahaman mengenai kerja keras orangorang yang memiliki andil dalam pembangunan bangsa yang besar dan kuat (Jarolimek, 1986).

Melalui penelitian ini dilakukan suatu kajian yang dapat mengembangkan nasionalisme, patriotisme, dan toleransi dengan mengambil materi tentang peranan golongan minoritas, dalam hal ini peranakan Arab di Indonesia. Kajian tentang peranan keturunan Arab pada periode masa pergerakan sampai revolusi kemerdekaan telah menjadi kajian pada penelitian sebelumnya di tahun 2020. Hasil penelitian tersebut menghasilkan dokumen kajian tentang peranan peranakan Arab pada periode sejarah bangsa Indonesia. Kajian ini akan menjadi bermakna apabila kemudian dikembangkan dalam proses pembelajaran yaitu dengan mengembangkannya sebagai enrichment (pengayaan). Diharapkan dengan adanya kajian ini dapat memperkaya pembelajaran sejarah juga mengajak generasi muda khususnya siswa SMA meningkatkan kecintaan, kesetiaan, dan ketaatan pada negara agar dapat terlibat aktif membangun bangsa. Pengalaman yang pernah dialami masyarakat terdahulu menjadi pengetahuan berharga dan diperlukan dalam pendidikan sejarah sebagai langkah membangun nila positif dalam diri siswa (Hasan, 2012).

\section{METODE}

Penulisan artikel ini dilakukan dengan pendekatan kualitatif menggunakan metode sejarah. Metode penelitian sejarah menurut Garraghan (1957) dalam Wasino dan Hartatik (2018) dapat didefinisikan sebagai suatu kumpulan yang sistematis dari prinsip-prinsip dan aturan-aturan yang dimaksudkan untuk membantu dengan secara efektif dalam pengumpulan bahanbahan sumber dari sejarah, dalam menilai atau menguji sumber-sumber itu secara kritis, dan menyajikan suatu hasil "sintesis" (pada umumnya dalam bentuk tertulis) dari hasil-hasil yang dicapai.

Dari pengertian tersebut, terdapat tiga langkah atau tahap kegiatan di dalam metode penelitian sejarah, yaitu: (1) Pencarian bahan-bahan sumber di atas kita dapat bekerja, ialah pencarian sumber-sumber keterangan atau pencarian bukti-bukti sejarah, tahap ini disebut heuristik, yang merupakan langkah permulaan di dalam semua penulisan sejarah. (2) Penilaian atau pengujian terhadap bahan-bahan sumber tersebut dari sudut pandangan nilai kenyataan (kebenarannya) sematamata, tahap kedua ini disebut kritik sumber, yang merupakan langkah yang sangat penting sehingga sering 
HISTORIA: Jurnal Pendidik dan Peneliti Sejarah, 5(1), 1-8. https://doi.org/10.17509/historia.v4i2.30197

dikatakan bahwa seluruh proses dari metode sejarah disebut sebagai kritisisme sejarah. (3) Penceritaan atau penyajian yang bersifat formal (resmi) dari penemuanpenemuan dari kegiatan heuristik dan kritik; tahap ketiga ini meliputi penyusunan kumpulan dari data sejarah dan penyajian / penceritaannya (pada umumnya dalam bentuk tertulis) di dalam batas-batas kebenaran yang objektif dan arti atau maknanya; tahap ketiga ini disebut Sinthese dan Penyajian (Sintesis dan Penulisan).

\section{PEMBAHASAN}

\section{Tinjauan Historis Proses Asimilasi Keturunan Arab di Indonesia}

Semenjak penetapan kebijakan asimilasi bagi seluruh aspek kehidupan untuk orang Arab di tahun 1967, pelaksanaan kebijakan tersebut tidak dapat dikatakan terlaksana dengan mudah. Dibutuhkan waktu dan proses yang tidak sebentar demi menggapai keinginan pemerintah orde baru dengan kebijakan asimilasinya. Keppres Nomor 240 Tahun 1967 bab II tentang Pembinaan Warga Negara Indonesia Keturunan Asing pasal menyebutkan :

"Warga Negara Indonesia keturunan asing diberi kesempatan jang sama dengan warga Negara Indonesia asli dalam mengerahkan daja dan dananja disegala bidang untuk mempertjepat pembangunan serta meningkatkan kemakmuran dan kesedjahteraan Bangsa dan Negara".

Ini mengartikan keturunan Arab mendapatkan keleluasaan menata dan menggali juga mengembangkan kapabilitas dirinya sebagai langkah guna mempercepat asimilasi dalam perekonomian.

Politik segregasi yang dikembangkan pada masa pemerintah kolonial Belanda menjadikan terbentuknya perkampungan-perkampungan yang dihuni oleh kelompok etnis tertentu. Kebijakan segregasi tersebut dikembangkan melalui wijkenstelsel yang pada awalnya diberlakukan bagi penduduk keturunan Tionghoa, hanya kemudian bagi etnis lain juga terbentuk pemukiman-pemukiman yang terkonsentrasi berdasarkan etnisnya tersebut. Politik segregasi ini merupakan polarisasi dari kebijakan kolonial yang memberlakukan "divide and rule". Dampak selanjutnya bahwa dengan segregasi ini menyebabkan terbatasnya kontak sosial antar kelompok, menumbuhkan prejudice dan memperkuat identitas etnik sehingga akhirnya akan berkembang pemisahan, pengelompokan dan kompetisi antar etnik terutama di bidang ekonomi dan politik (Aziz, Amla, \& Hardiana, 2010).

Mayoritas keturunan Arab yang ada di Indonesia asal muasalnya adalah dari daerah Hadramaut, Yaman selatan. Ada pula keturunan Arab di Indonesia yang berasal dari negara Timur Tengah dan Afrika lainnya, misalnya dari Mesir, Arab Saudi, Sudan atau Maroko; namun memiliki kuantitas yang lebih sedikit dibandingkan dengan keturunan Hadramaut. Tujuan kedatangan mereka mulanya adalah berdagang sekaligus bedakwah, namun berangsur-angsur bermukim bahkan berkeluarga dengan masyarakat lokal.

Mulanya para perantau Arab-Hadramaut datang ke Nusantara secara massal pada paruh terakhir abad ke-18 $\mathrm{M}$, namun banyak dari mereka mulai menetap di pulau Jawa setelah tahun $1820 \mathrm{M}$ sedangkan koloni mereka lainnya tiba di Timur Nusantara pada 1870 M. Berdasarkan hasil Penelitian Berg (2010) terdapat stratifikasi sosial bagi masyarakat Hadramaut yang ada di Nusantara, yaitu golongan sayid, suku-suku, juga golongan menengah. Awalnya migran Hadramaut yang datang ke Nusantara didominasi oleh golongan sayid namun masa kemudian kelompok masyarakat dari sistem stratifikasi sosial lain mengikuti jejak sayid tersebut.

Di daerah asal mereka, Hadramaut, golongan sayid merupakan kelompok bangsawan yang sangat dihormati juga berpengaruh dikarenakan silsilah mereka sebagai keturunan Nabi Muhammad. Golongan suku-suku sebagai kelompok masyarakat di luar keturunan Nabi Muhammad namun memiliki kedudukan tinggi dikarenakan merupakan penduduk asli Hadramaut. Kelompok ini terbagi dalam dua golongan yaitu qabilah sebagai penduduk asli Hadramaut dan syaikh para pendatang yang menikahi penduduk asli Hadramaut. Golongan syaikh (masyaikh) sebagai kelompok masyarakat yang memiliki pengetahuan tertentu, terutama dalam agama. Selain itu, golongan menegah sebagai kelompok penduduk bebas yang terdiri dari pedagang, pengrajin, petani dan pembantu (Berg, 2010)..

Orang Arab yang merantau ke Nusantara ini kemudian mencorakkan diri mereka dengan pembentukan koloni di berbagai wilayah, di antaranya adalah Batavia lebih tepatnya di Pekojan. Pada awalnya tempat ini ditempati oleh mayoritas umat muslim India yang berasal dari Gujarat, Coromandel, dan Malabar. Namun ketika pendatang Arab dari Hadramaut datang secara massal - terlebih ketika munculnya transportasi kapal uap dan dibukanya terusan Suez 1869 M, penguasaan Pekojan berpindah tangan pada pendatang Hadramaut. Maka dari itu pada tahun $1844 \mathrm{M}$ pemerintah Hindia-Belanda mengharuskan kelompok Arab untuk memilih kepala koloni yang mereka sebut sebagai kapiten atau kapten Arab atau Leuitenant Arab. Kepala koloni ini dipilih oleh Bupati dan diangkat oleh Residen dengan berdasar pada pertimbangan penasihat urusan dalam negeri. 
Para pendatang Arab yang datang mayoritas merupakan pedagang dan sebagian kecil di antaranya berprofesi juga sebagai juru dakwah. Seperti pedagang pada umumnya, setelah sampai pada tempat tujuan mereka tidak lantas pergi kembali ke tempat asal mereka melainkan harus menunggu dagangan habis dan membawa dagangan baru juga menunggu musim yang menentukan waktu pelayaran yang tepat. Kondisi ini menyebabkan mereka menetap sementara di tanah perantauan selama beberapa waktu. Selama di masa perantauan mereka menjalin hubungan dengan penduduk setempat, tidak jarang interaksi antara pedagang juga masyarakat lokal ini berakhir pada pernikahan putri mereka pada para perantau khususnya bagi perantau yang memiliki tingkatan strata sosial yang tinggi seperti kelompok sayid.

Dari hubungan ini kemudian lahir keturunan Arab campuran yang biasa disebut sebagai peranakan Arab atau muwalad. Dengan munculnya anak-anak peranakan ini, semakin menambah jumlah orang Arab di Nusantara. Terlebih dengan adanya peraturan wijkenstelsel dan passenstelsel yang mengatur pernikahan Arab sebelumnya dengan wanita pribumi, beralih menikahi wanita etnis mereka sendiri termasuk pernikahan keturunan campuran generasi mereka. Hal ini semakin menambah besar jumlah mereka dan semakin mengikat rasa kekerabatan di antara mereka.

Dalam kasus keturunan Arab di Indonesia, proses asimilasi relatif berhasil terutama karena kesamaan agama Islam dan peranan keturunan Arab sebagai penyebar Islam. Terjalinnya terus komunikasi khususnya di masjid dan pasar, serta sering terjadinya perkawinan campur menyebabkan "kampung Arab" di banyak kota sudah berbaur dengan perumahan penduduk asli. Demikian pula pemikiran-pemikiran Islam yang datang dari Timur Tengah bermacam-macam dan di Timur Tengah tidak pernah ada satu "nation state" yang kuat yang bisa memperoleh loyalitas dari keturunan Arab. Bahkan sampai akhir Perang Dunia I, sebagian besar wilayah Arab ada di bawah kekuasaan dinasti Usmaniyah (Ottoman Empire) dari Turki. Dengan demikian, loyalitas keturunan Arab hanyalah kepada negaranegara yang didiaminya di Asia Tenggara, termasuk di Indonesia. Tidak mengherankan jika banyak tokohtokoh keturunan Arab menjadi pelopor gerakan nasional seperti di Malaysia, maupun di Indonesia, seperti ditunjukkan oleh pendirian Partai Arab Indonesia.

Perkembangan dan kondisi keturunan Arab ini berbeda dengan keturunan Tionghoa. Hal ini disebabkan baik karena perbedaan jumlah migran, besar pemukiman (Pecinan), sifat hubungan dengan negeri asal, tingkat asimilasi sosial politik maupun persaingan peradaban
Cina dengan peradaban Melayu dan Jawa. Secara politik, keturunan Arab Indonesia bisa melakukan proses integrasi dimana setelah Partai Arab Indonesia dibubarkan maka mereka kemudian terus bergabung dengan partai-partai nasional. Integrasi ini menjadikan mereka menjadi bagian dari masyarakat Indonesia bukan lagi menjadi bagian dari minoritas (Henrard, 2020). Demikian juga dalam hal pendidikan, berbeda dengan sekolah Tionghoa, sekolah keturunan Arab lebih adaptif terhadap kurikulum yang diterapkan pemerintah. Sekolah-sekolah yang dikelola keturunan Arab seperti Djamiatul Chaer dan Al Irsyad sejak awal menggunakan kurikulum yang sesuai dengan kurikulum Pemerintah.

\section{Kajian Tentang Peranan Peranakan Arab Pada Masa Pergerakan Kemerdekaan Indonesia}

Menurut Smith (1997) bahwa pergulatan identitas orang Arab-Hadrami sebagai akibat dari diaspora, dapat dirujuk pada fenomena diaspora "tua", yang telah berlangsung dalam skala besar sejak pertengahan abad ke-18 hingga akhir 1950-an. Pada situasi diskriminasi yang tinggi sebagai ciri bermasyarakat masa Kolonial Belanda, orang-rang Hadrami memiliki peranan pada bidang sosial, politik maupun ekonomi. Mereka mendapat bagian untuk memperluas pasar bisnis, memperoleh kesejahteraan dan mengirimkannya kembali ke tanah Hadramau (Alatas, 2015).

Hubungan kontak antara Jawa dan Hadramaut menjadi saksi eksistensi komunitas ini di kawasan Asia Tenggara. Para perantau tidak hanya mengirimkan uang namun juga anak-anak mereka ke Hadramaut untuk memperoleh pendidikan. Bahkan dalam perkembangannya, sebagian dari mereka menjalin kontak dengan politik Hadramaut (Jonge \& Kaptein, 2002). Namun dikarenakan gagasan nasionalisme dan diskursus mengenai nation-states, aktivitas ini menurun drastis (Slama, 2005).

Hasil dari diaspora Hadrami di Nusantara terlihat pada pendirian institusi pendidikan modern, seperti Jam'iyyat Khair dan Jam'iyyah al-Islah wa al- Irsyad (AlIrsyad). Kedua lembaga pendidikan ini menghasilkan dua kelompok besar dalam internal komunitas ArabHadrami, yakni tradisionalis (Jam'iyyat Khair) yang diisi oleh golongan Alawiyin (Ar-Rabithah) dan reformis yang diisi oleh golongan Al-Irsyad (Kesheh, 1999). Tidak hanya mewakili pertentangan pada daerah asal mereka, namun juga pada wilayah tanah air mereka yang baru. Perselisihan kelompok sayid dengan corak tradisional dan non-sayid dengan ciri reformis telah menjelma mulanya perdebatan sosiall menjadi perdebatan doctrinal (Rijal, 2017). 
HISTORIA: Jurnal Pendidik dan Peneliti Sejarah, 5(1), 1-8. https://doi.org/10.17509/historia.v4i2.30197

Sebuah hal yang menarik dari fase ini adalah munculnya intelektual-intelektual "baru" yang "progresif" terlibat dalam diskursus menjadi pihak penggerak kebangkitan Arab-Hadrami di Indonesia, baik dari golongan sayid maupun golongan non-sayid. Diskursus juga telah mengubah perdebatan di antara keduanya menjadi totok dan peranakan.

Peran keturunan Arab di Indonesia didominasi pada sektor perdagangan namun tetap berhubungan dengan penyebaran dan pengukuhan Islam seperti peran sebagai guru agama; dai; mendirikan sekolah agama; sebagai penyantun dan donatur aktifitas keagamaan; sebagai pejuang melawan hal-hal yang bertentangan dengan Islam; aktif dalam organisasi yang berafiliasi dengan kegiatan keagamaan dan sebagainya. Banyak pusat pendidikan agama Islam, tokoh-tokoh agama Islam, kegiatan yang berhubungan dengan sejarah Islam di Indonesia berkaitan erat dengan keturunan Arab.

Peranan orang-orang Arab pada bidang sosialkeagamaan sangat mencolok ketika memasuki awal abad ke-20 M, dengan pendirian organisasi modern Jamiyyat Khair tahun 1905. Organisasi ini terkenal dengan pendirian sekolah Islam modern juga kegiatan bersifat keagamaan lain terutama pada tokoh organisasi yang berinisiatif mendirikan lembaga khusus yang bernama ar-Rabithah al-Alawiyyah. Berdiri pada 1928 $\mathrm{M}$ atas inisiatif Sayyid Ahmad bin Abdullah Assegaf dan Sayyid Muhammad bin Abdurrahman bin Ali bin Shahabuddin, lembaga ini didaftarkan pada pemerintah Hindia-Belanda dan tercatat dalam akte Notaris Mr. A.H. Van Ophuijsen No. 66 tanggal 16 Januari 1928. Disahkan pemerintah Belanda pada 27 Desember $1928 \mathrm{M}$ dengan penandatanganan oleh G.R. Erdbrink seorang sekretaris pemerintah Hindia-Belanda.

Puncak peranan bangsa Arab di Nusantara adalah Konferensi Keturunan Arab pada 3-5 Oktober 1934 di Semarang yang melahirkan Sumpah Pemuda Arab di Semarang. Sumpah pemuda ini merupakan bentuk kesepakatan internal orang Hadrami dan merupakan sebuah langkah revolusioner. Hal yang paling disoroti dalam konferensi ini yaitu tiga butir pernyataan Sumpah Pemuda Keturunan Arab, yaitu:

1. Tanah Air Peranakan (Keturunan) Arab adalah Indonesia.

2. Peranakan Arab harus meninggalkan kehidupan menyendiri (mengisolasi diri).

3. Peranakan Arab harus memenuhi kewajibannya terhadap tanah air dan bangsa Indonesia (Hayaze', 2017). Sumpah Pemuda Arab 1934 merupakan langkah yang revolusioner, tidak hanya bagi masyarakat keturunan Arab namun juga bagi seluruh bangsa Indonesia. Sumpah Pemuda Arab 1934 juga kelahiran PAI
(Partai Arab Indonesia) mengundang reaksi seluruh masyarakat berbagai etnis baik di kalangan keturunan Arab maupun di luar kalangan Arab seperti Jawa, Cina, dan Belanda. Kalangan Arab-Hadrami yang menyetujui gagasan ini sebagian besar merupakan kelompok masyarakat dengan latar belakang non-sayid dan sayid "progresif". Golongan sayid yang setuju terhadap gagasan Sumpah Pemuda Arab dan pengukuhan menjadi PAI menyebabkan stratifikasi sosial sebelumnya yang didasarkan pada genealogi "suci" Nabi menjadi longgar dan tidak ada lagi. Secara psikologis hal ini dapat dipahami sebab akan meningkatkan harkat dan martabat mereka pada posisi yang setara dengan kelompok keturunan Nabi.

Keturunan Arab di Indonesia banyak berkiprah dalam kehidupan masyarakat Indonesia. Apabila kita membuka google dan menuliskan tokoh Peranakan arab di Indonesia, maka akan mumcul sejumlah nama dengan beragam profesi dan perannya di masyarakat mulai dari dunia hiburan, penyanyi, penulis, pelukis sampai pada tokoh politik. Hal ini menunjukkan bahwa ketrununan Arab Indonesia telah berbaur dan terlibat aktif dalam kehidupan masyarakat Indonesia dalam berbagai bidang. Diantara tokoh-tokoh penting yang berasal dari keturunan Arab adalah:

\section{Raden Saleh}

Lahir pada tahun 1807, pemilik nama lengkap Raden Saleh Sjarif Bustaman adalah pelukis Indonesia keturunan Arab-Jawa yang mempionerkan seni modern Indonesia (saat itu Hindia Belanda). Raden Saleh dilahirkan di keluarga Jawa ningrat. Dia cucu dari Sayyid Abdoellah Boestaman dari sisi ibunya. Ayahnya adalah Sayyid Hoesen bin Alwi bin Awal bin Jahja, seorang keturunan Arab. Ibunya bernama Mas Adjeng Zarip Hoesen, tinggal di daerah Terboyo, dekat Semarang. Sejak 10 tahun, ia diserahkan pamannya, Bupati Semarang, kepada orang-orang Belanda atasannya di Batavia. Kegemaran menggambar mulai menonjol sewaktu bersekolah di sekolah rakyat (Volks-School).

Keramahannya bergaul memudahkannya masuk ke lingkungan orang Belanda dan lembaga-lembaga elite Hindia Belanda. Raden Saleh mendapat beasiswa untuk belajar di negeri Belanda tahun 1829. Di sana ia berkenalan dengan kalangan ningrat dari banyak istana di Eropa, khususnya dengan Grojbherzog von SachsenCorburg-Gotha. Dialah pelukis Indonesia yang paling berbakat dan berhasil pada abad ke 19. Raden Saleh adalah pelukis Jawa pertama yang secara sistematis menggunakan cat minyak dan mengambil teknik-teknik Barat: realisme pada potret, pencarian gerak, perspektif, dan komposisi berbentuk piramid dan sebagainya. Kini ia dikenal sebagai "bapak" ilmu seni lukis Indonesia. 


\section{Habib Abubakar bin Ali Shahab}

Habib Abubakar bin Ali Shahab adalah tokoh keturunan Arab-Indonesia yang aktif dalam pergerakan dan pendidikan Islam pada masa pra-kemerdekaan Indonesia. Dia juga tercatat sebagai pendiri Jamiat Kheir dan Malja Al Shahab. Lahir di Jakarta 24 Oktober 1870 dari ayah Ali bin Abubakar bin Umar Shahab, kelahiran Damun, Tarim, Hadramaut dan ibu Muznah binti Syech Said Naum. Dalam situasi dan tekanan kolonial yang keras, Habib Abubakar tampil untuk mendirikan sebuah perguruan Islam, yang bukan hanya mengajarkan agama, tetapi juga pendidikan umum.

Pada tahun 1901, bersamaan dengan maraknya kebangkitan Islam di Tanah Air, berdirilah perguruan Islam Jamiat Kheir. Pada saat pertama kali berdiri, perguruan ini membuka sekolah di kawasan Pekojan yang saat itu penghuninya banyak keturunan Arab. Selain Habib Abubakar, turut serta mendirikan perguruan ini sejumlah pemuda Alawiyyin yang mempunyai kesamaan pendapat dan tekad untuk memajukan Islam di Indonesia, sekaligus melawan propagandapropaganda Belanda yang anti Islam. Di Tanah Abang, Habib Abubakar bersama-sama sejumlah Alawiyyin juga mendirikan sekolah untuk putra (aulad) di Jalan Karet dan putri (banat) di Jalan Kebon Melati (kini Jalan Kebon Kacang Raya), serta cabang Jamiat Kheir di Tanah Tinggi, Senen.

\section{Abdurrahman Baswedan}

Abdurrahman Baswedan atau AR Baswedan merupakan seorang diplomat dan sastrawan Indonesia juga pejuang kemerdekaan Indonesia. Beliau lahir di Surabaya, 9 September 1908 dengan riwayat pernah menjadi salah satu anggota Badan Penyelidik Usaha dan Persiapan Kemerdekaan Indonesia (BPUPKI), Wakil Menteri Muda Penerangan RI pada Kabinet Sjahrir, Anggota Badan Pekerja Komite Nasional Indonesia Pusat (BP-KNIP), Anggota Parlemen dan Anggota Dewan Konstituante. AR Baswedan yang bertugas sebagai diplomat telah berhasil menarik perhatian dunia internasional dan mendapatkan pengakuan de jure dan de facto pertama dari Mesir. AR Baswedan merupakan peranakan Arab yang fasih berbahasa Jawa. Selama masa perjuangannya, beliau sering kali menyerukan keturunan Arab lain untuk bersatu memperjuangkan Indonesia. Ia mengajak keturunan Arab, seperti dirinya sendiri, menganut asas kewarganegaraan ius soli, di mana saya lahir, di situlah tanah airku.

\section{Faradj bin Said}

Faradj bin Said merupakan sebuah pengusaha Indonesia keturunan Arab yang pada saat peristiwa kemerdekaan telah merelakan rumahnya di Jalan Pegangsaan Timur nomor 56 digunakan untuk upacara proklamasi. Selama bersama Bung Karno, beliau memberikan pelayanan termasuk membantu menyembuhkan penyakit beliau. Faradj bin Said lahir di Hadramaut, Yaman Selatan dan menetap di Indonesia dengan menjalankan sebuah perusahaan. Atas jasanya ini, pemerintah RI memberikan ucapan terima kasih dan penghargaan kepada Faradj bin Said Awad Martak yang disampaikan tertulis atas nama Pemerintah Indonesia pada tanggal 14 Agustus 1950, ditandatangani oleh Ir HM Sitompul selaku Menteri Pekerdjaan Umum dan Perhubungan Republik Indonesia.

\section{Enrichment Materi Tentang Peranakan Arab Dalam Buku Teks Pelajaran Sejarah di Indonesia}

Meskipun dalam konteks yang berbeda. Kita dapat merujuk pendapat Montessori tentang prinsip enrichment dalam proses pembelajaran. Montessori berpandangan bahwa perbedaan dalam kemampuan belajar dan berperilaku pada hakekatnya merupakan masalah pendidikan. Anak-anak. Dalam hal ini siswa memiliki potensi dan kapasitas yang besar untuk melakukan pendidikan secara mandiri, konsentrasi dan pengulangan dan stamina yang membantu mereka menyimpulkan pembelajaran terbaik terjadi jika kondisi belajar disesuaikan dengan kemampuan anak. Penekanan konsentrasi, perkembangan inisiatif dan kondisi belajar menjadi penekanan utama Montessori untuk dapat memberikan ruang bagi siswa memperoleh rasa pencapaian pribadi. Struktur dan kebebasan yang saling terkait ini pula menekankan proses belajar yang seharusnya menciptakan fondasi bagi kedisiplinan dan keahlian yang relevan dengan kehidupan mereka (Befring, 2006).

Program enrichment menurut sebuah sumber yang didapatkan dari situs Tools for School, April 1998, pada dasarnya dikembangkan berdasarkan prinsip sebagai berikut :

a. Each learner is unique.

b. Learning is more effective when students enjoy what they are doing.

c. Learning is more meaningful and enjoyable when content and process are learned within the context of a real and present problem. 
Sementara itu program enrichment menurut Clark (1988) yang mengutip pendapat Galagher dapat mengembangkan sebuah aktivitas yang membangun:

a. the ability to associate and interrelate concepts.

b. the ability to evaluate facts and arguments critically.

c. the ability to create new ideas and originate new lines of thought.

d. the ability to reason through complex problem.

e. the ability to understand other situations, other times, and other people; to be less bound by one's own peculiar environmental surroundings.

Program pengayaan atau enrichment merupakan suatu hal yang patut menjadi perhatian dalam program pendidikan. Siswa di dalam kelas menunjukkan sebuah kemampuan yang beragam. Siswa yang berada pada level kemampuan menengah dan bawah seringkali mendapat perhatian dalam pengertian bahwa mereka diberikan kesempatan untuk menguasai sebuah materi pembelajaran melalui kegiatan remedial teaching. Dan kegiatan ini merupakan kegiatan yang dapat kita temukan pada beberapa sekolah. Akan tetapi untuk mereka yang memiliki kemampuan di atas rata-rata tidak bias diperlakukan sama. Pada proses pembelajaran yang normal, anak-anak unggulan mungkin saja memiliki kemampuan yang diharapkan atau lebih sehingga mereka tidak perlu lagi mendapatkan remedial teaching. Akan tetapi bukan juga berarti bahwa anak-anak kelompok unggulan hanya dibiarkan memperoleh kemampuan sampai pada batas yang telah ditetapkan. Kemampuan mereka perlu terus ditingkatkan melalui kegiatan pengayaan/enrichment. Oleh karena itu menurut Renzulli, program enrichment adalah merupakan program yang special yang bisa saja keluar dari konteks kurikulum yang berlaku ataupun kegiatan pembelajaran konvensional.

Salah satu sarana dalam pembelajaran yang dijadikan media untuk menyampaikan materi kepada peserta didik adalah buku teks. Di dalam buku teks terdapat tujuan pedagogis yang mengacu pada suatu disiplin ilmu tertentu. Buku teks biasanya ditulis oleh guru ataupun pakar sesuai dengan bidang disiplin ilmunya. Demikian halnya dengan buku teks pelajaran sejarah yang dijadikan suatu sumber serta media bagi guru untuk menyampaikan materi yang berkaitan dengan peristiwa yang pernah terjadi dimasa lalu.

Secara ideal buku teks pelajaran sejarah harus memberikan informasi yang mengandung nilai-nilai pendidikan. Sebab dengan belajar sejarah, disamping memperoleh pengetahuan tentang fakta-fakta sejarah, akan tetapi juga harus mendapatkan pemahaman atau penghargaan mengenai peristiwa, periode atau masyarakat yang hidup di masa lalu (Garvey \& Krug,
2015). Penghargaan terhadap suatu peristiwa yang terjadi di masa lalu tersebut akan memberikan pelajaran terhadap manusia atau generasi yang hidup saat ini. Pelajaran dalam sejarah dapat berupa nilai-nilai, misalnya nasionalisme, patriotisme, dan sebagainya. Dengan demikian buku teks pelajaran sejarah, tidak hanya memberikan pengetahuan tentang fakta sejarah, tetapi juga memberikan pelajaran tentang arti pentingnya peristiwa sejarah.

Materi dalam buku teks pelajaran sejarah di sekolah disesuaikan dengan kurikulum yang berlaku lebih banyak memuat materi tentang sejarah Indonesia. Sementara sejarah kawasan atau sejarah dunia hanya sebagian kecil saja dipelajari melalui mata pelajaran sejarah dalam kelompok peminatan. Sejarah Indonesia diuraikan lebih luas mulai dari jaman pra sejarah, jaman Hindu Budha, jaman Islam, jaman penjajahan, jaman kemerdekaan, zaman revolusi, Orde Lama, Orde Baru, hingga Orde Reformasi. Periodisasi yang digunakan lebih pada pendekatan politik. Dalam periodisasi politik arah dari suatu perkembangan dan perubahan sejarah menuju pada suatu terbentuknya negara atau kekuasaan. Negara yang dimaksud dalam historiografi dalam buku teks adalah negara Republik Indonesia yang telah merdeka.

Pengorganisasian materi ditujukan pada buku teks dengan tujuan menyesuaikan tahapan pencapaian tujuan yang ada dalam kurikulum. Buku teks menjadi sebuah media yang dianggap mampu untuk menanamkan nasionalisme bila berisi uraian fakta historis dan interpretasi yang menumbuhkan kesadaran diri sebagai warga bangsa dan sebagai bentuk pengembangan kemampuan membuat keputusan yang dapat dipertanggungjawabkan baik secara rasional maupun moral bagi pembaca. Dalam tingkat kurikuler, buku teks pelajaran sejarah dituntut memuat uraianyangmencakup pembangunan karakteratauidentitas kultural nasional yang kuat, memberikan dorongan sebagai bentuk penjagaan kohesivitas juga progresivitas masyarakat dan bentuk pengembangan kemampuan akademik yang tinggi bagi siswa sebagai pembaca.

Di dalam buku-buku teks sejarah di persekolahan, kajian tentang peran-peran masyarakat secara spesifik memang tidak terlalu banyak diungkap. Termasuk dalam hal ini peran dari keturunan Arab. Materi-materi sejarah di persekolahan bisa diperkaya dengan kajian terhadap peran-peran kelompok minoritas. Misalnya pada materi tentang proses masuk dan berkembangnya Islam di Indonesia, bisa digali tentang peranan para pendatang Arab ini dalam proses penyebaran Islam, termasuk bagaimana peran mereka dalam struktur politik pada saat itu yang bahkan bisa memasuki kancah sebagai penguasa, sebagai Sultan kerajaan Islam. Contoh lain pada masa pergerakan kebangsaan bisa ditambahkan 
dengan materi terbentuknya Partai Arab Indonesia dan peran dari Sumpah Pemuda Arab yang merefleksikan integrasi dan proses mereka yang menjadikan Indonesia sebagai bangsa dan negaranya.

\section{SIMPULAN}

Salah satu kekayaan bangsa Indonesia dari sisi etnik adalah dengan hadirnya kelompok minoritas yang berasal dari keturunan Arab. Sebagian besar keturunan Arab tersebut berasal dari daerah Hadramaut, Yaman Selatan. Komunitas Arab di Indonesia telah menjadi bagian dari penduduk dan warga Negara Indonesia. Peran mereka selain sebagai pedagang juga bergerak di bidang keagamaan Islam, dalam menyebarluaskan pengaruh agama Islam.

Proses asimilasi keturunan Arab di Indonesia terhitung lebih berhasil dibandingkan dengan etnis keturunan lainnya, terutama China. Hal ini disebabkan karena kesamaan agama dan peranan mereka yang dominan dalam penyebaran agama Islam. Selain itu pola interaksi yang lebih terbuka dalam system perdagangan dan pemukiman menyebabkan proses asimilasi keturunan Arab lebih kuat. Hal ini juga diperkuat secara politik tidak ada tendensi keturunan Arab untuk menegakkan identitas kebangsaan dan Negara pada daerah asalnya. Sebagai bagian dari warga Negara Indonesia dengan demikian peranan mereka perlu diungkap dan dijadikan sebagai bahan materi pembelajaran sejarah.

\section{REFERENSI}

Alatas, I. F . (2015). Gold and silver,branded horses, and well-tilled land: gender and hadrami migration. Indonesia Feminist Journal, 3(1): 4-13.

Aziz, Z., Salleh, A., \& Ribu, H. E. (2010). A study of national integration: Impact of multicultural values. Procedia-Social and Behavioral Sciences, 7, 691-700. 10.1016/j.sbspro.2010.10.094.

Befring, E., Thousand, J. S., \& Nevin, A. (2000). From normalization to enrichment. A retrospective analysis of the transformation of special education principles. Restructuring for caring and effective education. Baltimore: Paul Brooks Publishing.

Berg, L. W. C. van den. (2010). Orang arab di nusantara. Komunitas Bambu.

Clark, B. (1988). Growing up gifted. Bell \& Howell Co.
Garvey, B. \& Mary Krug. (2015). Model-model pembelajaran sejarah di sekolah menengah atas. Ombak.

Hasan, S.H. (2012). Pendidikan sejarah indonesia: Isu dalam ide dan pembelajaran. Rizky Press.

Henrard, K. (2000). Devising an adequate system of minority protection: individual human rights, minority rights, and the right to self-determination. Martinus Nijhoff Publishers.

Jarolimek, J. (1986). Social studies in elementary education. Macmillan Publishing Company.

Jonge, H. D. dan Nico Kaptein (2002). The Arab presence in southeast asia: some introductory remarks, dalam jonge, huub de dan nico kaptein (eds). transcending borders: arabs, politics, trade, and islam in southeast asia. KITLV Press.

Kesheh, N. M. (1999). The Hadrami awakening: Community and identity in the netherlands east indies, 1900-1942. Cornell Southeast Asia Program.

Kochhar. (2008). Pembelajaran sejarah. Grasindo.

Renier, G.J., (1961). History: It purpose and method. George Allen Unwin Ltd.

Rijal, S. (2017). Internal dynamics within hadhrami arabs in indonesia: From social hierarchy to islamic doctrine. Journal of Indonesia Islam, 11(1): 1-28. 10.15642/JIIS.2017.11.1.1-28

Sjamsuddin, H. (2005). Model-model pengajaran sejarah: beberapa alternative untuk SLTA. Dalam Suwirta, A., \& Saripudin, D (ed.). Sejarah dalam perubahan, penghormatan 70 tahun prof. dr. h. ismaun, m.pd., (hlm. 175-194). Historia Utama Press.

Slama, M. (2005). Indonesian hadhramis and the hadhramaut: an old diaspora and its new connections. Antropologi Indonesia, 29(2),107-113.

Smith, W. G. C. (1997). Hadhramaut and the hadhrami in the modern colonial era: an introductory survey. Freitag, U., \& William G. Clerence Smith (eds.), Hadhrami Traders, Scholars, and Statesmen in Indian Ocean,1750s-1960s. Brill.

Wasino \& Hartatik, E.S. (2018). Metode penelitian sejarah dari Riset hingga Penulisan. Magnum.

Wineburg, S. (2006). Berfikir historis, memetakan masa depan mengajarkan masa lalu. Yayasan Obor Indonesia.

Wiriaatmadja, R. (2002). Pendidikan sejarah di Indonesia, perspektiflokal, nasional dan global. Historia Utama Press. 